\title{
VOX POPULI OR ABDICATION OF RESPONSIBILITY?: THE INFLUENCE OF THE IRISH CITIZENS' ASSEMBLY ON THE PUBLIC DISCOURSE REGARDING ABORTION, 2016-2019
}

\begin{abstract}
The last four decades have witnessed enormous changes in the Republic of Ireland in terms of society, economy and politics. Formerly perceived as a poor, peripheral and "priest-ridden" country additionally plagued by political violence in Northern Ireland, over recent decades Irish voters have supported a series of "liberal causes". Indeed, nowhere is this more apparent than Ireland's laws concerning abortion, an issue which displayed a seismic shift not only among Irish voters but the political parties which claim to represent them, a shift clearly reflected in the public discourse. At the same time, it will be seen that the use of a Citizens' Assembly as an exercise in "deliberative democracy" has allowed mainstream political parties to pass responsibility, at least partially, for changes to controversial laws to an extra-parliamentary body, thereby allowing them to claim that they were following the will of "the people" and finally settle one of the longest running conflicts in Irish political life. Thus, this article seeks to examine and describe both how effective the Irish Citizens' Assembly was at achieving its stated goal and its influence on the nation's public discourse concerning the issue of abortion.
\end{abstract}




\section{Key words}

Ireland, abortion, citizens' assemblies, deliberative democracy

\section{Introduction}

The issue of legalising abortion in the Republic of Ireland has proved to be the country's longest-running political conflict, lasting far longer than "the Troubles" in Northern Ireland. Originating in the early 1980s, the first attempts at setting down specific laws concerning abortion were not aimed at liberalisation but restriction, through an anti-abortion constitutional amendment introduced in 1983. Within a decade, however, events were turned on their head when Ireland's Supreme Court interpreted this same amendment as permitting abortion in certain circumstances. Subsequent attempts through various referenda and legislation to restore Ireland's abortion ban occurred during a time of huge societal, economic and demographic change. As the issue became further dragged out, it became clear that Irish attitudes to abortion had also changed, partly due to anti-clerical reaction within society to a litany of scandals in the Roman Catholic Church, as well as increasing economic prosperity leading to greater independence from societal institutions and political parties. Thus, increasing wealth and modernisation, coupled with moving away from the Church, and the political parties which had supported it, began to be seen by a new generation as evidence that they had moved on from "poor, Catholic Ireland" to being part of a socially and politically progressive EU member state.

Ireland's two main political parties, Fianna Fáil and Fine Gael were now in a quandary. Having a common origin in Catholic and nationalist politics, mainly differing in their voter base and attitudes to Northern Ireland, neither party had an appetite for dealing with the issue head on. Even though Fine Gael was the more socially liberal of the two, it still had a large number of members based in mainly rural constituencies who were opposed to abortion being introduced. Moreover, until very recently it would have been electoral suicide for the Members of Parliament (Teachtaí Dála or TDs) of either party in most constituencies to vote for any law or support any constitutional change allowing abortion ${ }^{1}$. Even when political polling showed that the majority of Irish people

1 Term for those sitting in its lower house (the Dáil) while those sitting its upper house (the Seanad) are termed Seanadóirí or Senators. Together, Ireland"s Houses of Parliament are termed the Oireachtas. 
were in favour of liberalising Ireland's abortion laws, most TDs would have been very reluctant to support this, either publicly or privately. Thus, as we will see, the establishment of a Citizens' Assembly allowed a "way out" of the impasse by passing the buck to an extra-parliamentary body whose recommendations could be conveniently used as justification for supporting the popular will, despite one's personal position on abortion.

In a period of a perceived crisis concerning the raison d'être of parliamentary democracy following the economic and political crisis of 2008, citizens' assemblies or similar exercises in what is termed "deliberative democracy" were used in at least four European countries, namely Iceland in 2011, Belgium in 2012, Romania in 2013 and Ireland in 2012 and 2016-2017. In a basic sense, deliberative democracy may be defined as ordinary citizens using discussion to reach an agreement and make recommendations to government on issues of importance, and as a form of participatory democracy. In a stricter academic sense, however, it may be termed as "a process of reaching reasoned agreement among free and equal citizens' ensuring that they have an opportunity to express their views and preferences and justify their decisions within a deliberative process for the purpose of reaching conclusions that are collectively binding" (We the Citizens..., 2011). Canadian political scientist Simone Chambers has, along with others, termed such bodies as "mini-publics" which claim to have a mandate which "mirrors, represents, or speaks for some larger public", a development which may be observed in "a growing split in deliberative theory between theories of democratic deliberation ... which focus on discrete deliberative initiatives within democracies and theories of deliberative democracy ... that attempt to tackle the large questions of how the public, or civil society in general, relates to the state" (Chambers, 2009, pp. 323, 329).

However, since such experiments are a relatively new development, many academics now view them as a vehicle for moving their own theories concerning "deliberative democracy" from beyond the ivory towers of academia into the political sphere, perhaps even effecting legislative or constitutional change ${ }^{2}$. Moreover, as Irish constitutional lawyer Eoin Carolan has pointed out, the fact that much of the academic commentary on citizens' assemblies "comes from those who have been personally involved in either advocating for or organizing the events", means there is an inherent risk of positive bias (Carolan, 2015,

2 Two of the most recent works on deliberative democracy include Contiades \& Fotiadou, 2017; and Gastil \& Wright, 2019. 
p. 748). Indeed, Leib and Elmendorf have observed the academic discourse regarding citizens' assemblies is couched in terms as not only being in opposition to parliaments and the parties which run them, but as a progressive development to be lauded: "Deliberative democrats often see their advocacy for deliberation as necessary in part because of party politics that can too easily corrupt public discourse. Deliberative forums are routinely idealized as post-partisan affairs". (Leib \& Elmendorf, 2012, pp. 78-79). As this article seeks to assess to what degree the Irish Citizens' Assembly of 2016-2017 was successful at achieving its stated goal, as well as its influence on the nation's public discourse concerning the highly contentious issue abortion, it will focus employing deductive and comparative methods in analysing key legal documents, the reports of the citizens' assemblies concerned, as a well as articles which appeared in newspapers and other media outlets at the time.

\section{Background}

Although Ireland had gained its independence from the United Kingdom in 1922, much of its British statute law remained in force as long as in was not in conflict with Ireland's current Constitution of 1937. The law dealing with abortion was contained in sections 58 and 59 of the Offences Against the Person Act of 1861 which created two criminal offences. Section 58 made it unlawful for a woman to intentionally cause an abortion while Section 59 made it unlawful for a person to aid in ending a pregnancy (Offences Against the Person Act of 1861). Thus, subsequently, with Section 10 of the Health (Family Planning Act) of 1979, this constituted the law on abortion in Ireland under the 1937 Constitution, a situation which lasted until 1983.

However, as the courts had never authoritatively decided whether the Constitution required that abortion be prohibited in at least some cases, it could not be stated with certainty how the law on abortion was affected by the Constitution (Carolan, 2016, p. 5). Over the following decades, events in other Englishspeaking counties with a tradition of Common Law were to have a significant influence on how Ireland's abortion laws changed. The most significant of these was the United Kingdom's passing of the Abortion Act in 1967 which introduced lawful abortion to Great Britain (but not Northern Ireland) up to 28 weeks gestation for broadly interpreted conditions (Report of the Joint Committee, 2017, p. 31). The relative ease of access to abortion in a neighbouring jurisdiction saw, from 1980 on, some 170,000 Irish women vote with their feet to use Britain as 
a proxy abortion provider (McKay, 2019). It also relieved the Irish political class of confronting the issue directly since Britain had become a safety valve for Irish problem pregnancies.

Another factor which had a strong influence the debate in Ireland was the ruling by the United States Supreme Court in the Roe v. Wade case in 1973 which interpreted the constitutional right to privacy to mean that a woman had a constitutional right to have an abortion. As the Irish constitution also protects the individual's right to privacy, there was a fear that activist judges might follow the example of Roe v. Wade and interpret this right in the same manner. The ensuing debate during the next decade ultimately led, in 1983, to the Eighth Amendment (Article 40.3.3) to the Irish Constitution approved via a referendum by $67 \%$ of those who voted, and which stated that:

The State acknowledges the right to life of the unborn and, with due regard to the equal right to life of the mother, guarantees in its laws to respect, and, as far as practicable, by its laws to defend and vindicate that right (Article 40.3. 3 of the Constitution of Ireland).

Thus, Article 40. 3. 3 stating clearly that the unborn had a right to life under the Constitution apparently prevented both the Irish parliament (the Oireachtas) and the courts from violating this constitutional right, one which could only be amended by a majority vote in a referendum. However, since the text does not refer to abortion at all but enshrines the equal rights of the mother and the unborn as being equal as far as is practicable, this left it an open question as to whether there were cases where abortion would be justified under Irish law. Thus, the failure of Ireland's existing representative institutions to legislate for Article 40. 3. 3 created a legal vacuum where various court rulings were inevitable during the decades which followed. In fact, abortion was such a toxic electoral issue that the vast majority of TDs were more than happy for the courts to deal with it.

Of course, this would not have proved such a problem had international courts not become involved. In 1991 European Court of Justice ruled in a case referred from Ireland that abortion constituted a service under the Treaty of Rome. This meant that European Community (EC) Member States could not prohibit the distribution of information by agencies having a commercial relationship with foreign abortion clinics (SPUC v. Grogan \& Ors). Moreover, Ireland's abortion laws even ended up causing difficulties regarding international treaty negotiations with its EC partners. By early 1992, however, the Irish Government had negotiated a special protocol (Protocol 17) to the Maastricht Treaty which 
stated that nothing in European treaties would affect the operation of Article 40. 3. 3 (Protocol annexed to the Treaty on European Union, 1992, p. 205).

\section{The $X$ Case and its consequences}

Notwithstanding Ireland's attempts to draw red lines around its abortion laws, within days of the signing of the Maastricht Treaty on 7 February 1992, but before its ratification in Ireland, a case came before the High Court which would force the Irish government and people to confront the issue of abortion head on. This concerned Attorney General v. X103 (popularly known as "the X Case") (Attorney General 1992).

The defendant in the $X$ case was a fourteen-year-old girl, referred to as $X$ in order to protect her anonymity, who had become became pregnant after being raped by the father of a school-friend. Although the intention of $X$ 's parents was for her to have an abortion in the United Kingdom, Ireland's Attorney General, seeing his role as guardian of the public interest, applied for an interim injunction from the High Court restraining the girl and her parents from leaving the country (Fifth Progress Report, 2000, p. 21). When the case came to trial, the High Court heard oral testimony from a psychologist stating that there was a risk that the girl in question may commit suicide. When the High Court upheld the travel injunction sought by the Attorney General, the defendants appealed to the Supreme Court. Although the court upheld the travel injunction, Chief Justice Thomas Finlay, when considering the psychological evidence in the case, ruled that "there is a real and substantial risk to the life of the mother by self-destruction which can only be avoided by the termination of her pregnancy" (Fifth Progress Report, 2000, p. 21). In addition, since three members of the Court had taken the view that the right to travel had to be read subject to the right to life of the unborn, the Irish Government quickly negotiated a Solemn Declaration from Brussels stating that Protocol 17 of the Maastricht Treaty was not intended to limit freedom to travel or to obtain information available in Ireland related to services lawfully available in other EC countries (Bill Digest, 2018, p. 42).

Following on from the $X$ decision, three amendments were proposed to the Constitution in 1992 with the aim of: firstly, attempting to remove the threat of suicide as a justification for abortion; secondly, removing any restrictions on the right of Irish citizens to travel to other states; and thirdly, removing any restrictions on the right of Irish citizens to information legally available in those states. Of these proposed amendments, the first failed to pass while 
the remaining two were accepted (Fifth Progress Report, 2000, pp. 26-27). On the foot of the passing of the Fourteenth Amendment, in 1995, The Regulation of Information (Services outside the State for Termination of Pregnancies) Act was introduced, allowing doctors or appropriate agencies to give information about abortion to a pregnant woman in the context of full counselling as to all available options, but prohibiting any advocacy of abortion, or referral for abortion.

However, with Ireland's constitutional abortion quandary remaining unsolved and legislation unforthcoming, the vacuum remained for subsequent court rulings to complicate matters even further. In 1997, "the $C$ case" involved a thirteen-year-old girl who had become pregnant as the result of an alleged rape and who was granted the right to an abortion in Ireland based on the precedent set by the $X$ case (A \& B v. Eastern Health Board, 1998; Fifth Progress Report, 2000, p. 27).

The inadequacy of the situation was such as to attract unwanted international attention with criticism from the United Nations Committee for the Elimination of Discrimination Against Women. In 1999, the government established an Interdepartmental Working Group which produced a Green Paper on the subject of abortion. The paper was referred to the All-Party Oireachtas Committee on the Constitution for consideration which published its own Fifth Progress Report on Abortion in 2000. Unsurprisingly, the committee did not reach agreement on the substantive legal issue, with none of its proposed options gaining unanimous support. Once again Ireland's political representatives had failed to grasp the nettle concerning abortion. To be fair, their report was wide-ranging and examined the issues in depth and with consideration. Moreover, there was a large variety of views to be taken on board, some of which were diametrically opposed to each other (Fifth Progress Report, 2000, p. 27).

In 2002, the Irish government once again attempted, through a Twenty-Fifth Amendment to the Constitution, to reverse the $X$ case decision by excluding suicide as grounds for an abortion. This was a relatively complex proposal which would have amended the text of Article 40.3. 3 to refer to a future Oireachtas bill called The Protection of Human Life in Pregnancy Act, 2002. This law would not only outline how abortions were to be restricted in a legal sense but, unusually, could only be changed by referendum. However, this further effort to reverse the decision of the $X$ case failed by the narrowest of margins, with $50.42 \%$ of voters rejecting the proposal and $49.58 \%$ voting in favour (Bill Digest, 2018, p. 44). 
With two attempts at constitutional solutions having come to nothing, for the next decade or so the situation remained as it was in following the Supreme Court's decision in the $X$ case, namely; that an abortion can legally be carried out in Ireland where there is a real and substantial risk to the life of the mother which can only be avoided by termination of the pregnancy; and the risk to the life of the mother can come from a physical condition or from a risk of suicide. Although the $X$ case identified situations in which abortions could be lawfully performed, there was still much room for uncertainty regarding cases which differed from the $X$ or $C$ cases.

Moreover, international attention on the issue did not die away over the next few years with several United Nations committees and the European Human Rights Commissioner issuing their concerns either regarding Ireland's restrictive abortion laws or the lack of legislation to implement the decision of the $X$ case (Bill Digest, 2018, p. 44). Despite this, the Irish Government would continue to maintain that it was satisfied that pregnant women in Ireland were receiving all medical treatment necessary to safeguard their lives and that it had no plans to introduce any proposals regarding the constitution or legislation concerning abortion. Matters were made more complicated by the appearance of several cases before domestic and international courts, including challenges such as $D v$. Ireland claiming that Ireland's ban on abortion violated women's rights under the European Convention on Human Rights which came before the European Court of Human Rights (ECHR) in 2006.

Subsequently, in 2010, the ECHR delivered its judgement in $A, B$ \& $C v$. Ireland that this uncertainty in Irish law was a breach of the rights of one of the three women $(C)$ who she felt might be entitled to an abortion under Irish law, fearing that her pregnancy constituted a risk to her life for reasons relating to her previous treatment for cancer (Carolan, 2016, p. 9). The court unanimously held that C's Right to Respect for Family and Private Life had been infringed and that Ireland had failed to introduce any legislation which would have clarified her constitutional right to an abortion where her life was at risk (Bill Digest, 2018 , p. 44). Such pressure led the government, in 2012, to publish a report of an Expert Group on the judgement of $A, B, C v$. Ireland which established a legal framework setting out the criteria to be met when assessing whether an abortion was necessary to save a woman's life. 


\section{The Impact of the Savita Halappanavar Case on Ireland's Public Discourse on Abortion}

Two weeks before the Expert Group was due to publish its findings, a case occurred, not in court but in hospital, which was, rightly or wrongly, to colour many people's perception of the abortion debate, especially whether it had a role in saving a pregnant woman's life. This concerned Ms. Savita Halappanavar, a 31-year-old pregnant woman at 17 weeks gestation who was admitted to Galway University Hospital on 21 October 2012 but died seven days later. Shortly after her admission to hospital, as her waters had broken and a miscarriage seemed inevitable, Ms. Halappanavar had requested to have her pregnancy terminated and was told by medical staff that this was not possible as doctors had judged that there was no imminent threat to her life at that stage. However, once it became apparent that the patient was suffering from ascending genital tract sepsis, a decision was made to terminate the pregnancy due to the risk of infection on 24 October. Unfortunately, the patient's condition deteriorated and she died from cardiac arrest due to severe infection on the morning of 28 October.

A subsequent enquiry into Ms. Halappanavar's death by the Health Service Executive (HSE) in June 2013 found that, apart from a failure to screen the patient for septicaemia early enough, one causal factor in the death of Ms. Halappanavar was a failure to offer all management options to a patient experiencing inevitable miscarriage of an early second trimester pregnancy where the risk to the mother was increasing over time. Moreover, it was felt a lack of a clarity regarding Article 40. 3. 3 had impacted on the exercise of clinical professional judgment (O’Sullivan et al., 2013, pp. 4-6).

Although the facts of the case were initially unclear, pro-abortion groups and commentators quickly latched onto the incident as a cause célèbre and created a simplistic narrative that Ms. Halappanavar had died because she had been denied an abortion and was therefore a victim of Ireland's restrictive abortion laws. With this view being vocally supported by Ms. Halappanavar's grieving husband and family, her tragic death rapidly became politicised and drew worldwide media coverage and criticism. Even journalists normally critical of the Church's dominance in Ireland found this not just distasteful but dishonest. For instance, Eilis O'Hanlon writing in the Sunday Independent acknowledged that "collective compassion has to be harnessed to the cause of clarity, because the current nod-and-a-wink approach to difficulties in pregnancy is clearly unsatisfactory (...). It is plainly absurd that government after government has refused to face 
the issue of abortion", while accusing media outlets of reducing "a complex personal tragedy, about which few facts were still known, to a rallying call for a new abortion law (...) deaf to the testimony of doctors that what was being called for in this case was not an abortion but a routine clinical procedure carried out on thousands of women in Ireland" (O'Hanlon, 2012).

In such an atmosphere of domestic tension and international pressure, starting in January 2013, a Joint Committee on Health and Children held a series of public hearings involving relevant stakeholders, such as medical and legal experts, church representatives and advocacy groups on legislation concerning Article 40. 3. 3. This led to the publication of the Protection of Life in Pregnancy Bill in May, which was passed by the Oireachtas as The Protection of Life during Pregnancy Bill 2013 that July (O'Sullivan et al., 2013, pp. 4-6). The new law, which repealed sections 58 and 59 of the Offences Against the Person Act of 1861, gave legislative expression to the decision of the Supreme Court in the $X$ Case, namely that termination of pregnancy is lawful where there is a real and substantial risk to the life of the mother, including a risk of suicide. Otherwise, it would be an offence to intentionally destroy unborn human life, one punishable by an unlimited fine or imprisonment for up to 14 years or both (Bill Digest, pp. 46-47). It also laid down specific rules and procedures for a variety of situations and included rules regarding review procedures, conscientious objection for medical staff, as well as requiring an annual report on the operation of the system to be sent to the Minister for Health. Thus the report for 2015 stated that of 26 terminations carried out in Ireland that year, 14 were for a risk of physical illness, 9 in emergency circumstances, and 3 due to a risk of suicide (Carolan, 2016, pp. 11-12).

\section{The Establishment of the Citizens' Assembly as a response to increasing domestic and international pressure for abortion reform}

Despite the Irish government having finally legislated for a Supreme Court decision which had been issued thirteen years earlier, international pressure for further liberalisation of its abortion laws did not cease. The year 2015 saw both criticism of Ireland's "highly restrictive legislation on abortion" from the UN Committee on Economic, Social and Cultural Rights, as well as the drawing up of a proposed law espousing an abortion regime with few restrictions by a group of influential feminist legal experts led by Máiréad Enright (Enright et al., 2015). 
The following year, the UN Human Rights Committee found that in the case of Mellett v. Ireland, a pregnant woman carrying an unborn child diagnosed with a fatal foetal abnormality had her rights breached by denying her access to an abortion, and called for a change to the law for such cases. The pressure was kept up in 2016 when a third UN Committee, that on the Rights of the Child, expressed its concern regarding Ireland's new abortion law and adolescent health.

Realising that the 2013 Act was being subjected to strident criticism on both sides of the abortion debate, not only at home but abroad, the Irish government now looked for a way out of the impasse. The ultimate decision was influenced by a previously successfully experiment with a Constitutional Convention, lasting from 2012 to 2014, in which 66 randomly chosen citizens and 33 politicians had worked together over 15 months on nine constitutional questions. The inspiration for Ireland to use a Constitutional Convention had originated in two earlier public forums for "deliberative democracy" concerning electoral reform, the first which had taken place in the Canadian province of British Columbia in 2004 and the other in the Netherlands two years later. Greatly impressed with what he saw as a successful model, David Farrell, an Irish political scientist, decided with several colleagues to attempt to introduce a similar citizens' assembly to Ireland (McKay, 2019). Thus, in 2011, following the severe financial crisis of 2008, during which many Irish citizens had a crisis of confidence in their country's political, social and economic systems, Farrell, as part of a group of similarly minded researchers, intellectuals and activists, founded the We the Citizens movement. They soon established an informal "pilot" assembly whose aim was to demonstrate to the political class, and the Irish people in general, what the direct input of randomly selected "ordinary citizens" could mean for effecting positive and modernizing changes to Ireland's constitution (Courant, 2018, p. 5).

The result of this pilot assembly was a report requesting a constitutional citizens' assembly aimed at bringing about reform to the Irish political system and which was subsequently used to lobby politicians, civil servants, and representatives of civil society. Fortunately for the architects of this project, in 2012 a coalition of two political parties took power, namely Fine Gael and Labour, both of which had made election promises to introduce citizen-led constitutional reform. Although the Constitutional Convention was established later that year, the only serious and controversial issue it was allowed to deal with was that of same-sex marriage, an issue on which most political parties had no official policy, leading to accusations that politicians were involved in "a deeply cynical exercise" seeking to avoid directly dealing with the topic themselves (Whelan, 2012). As it turned out, directly as a result of the Convention's report, a same-sex 
marriage referendum took place on 22 May 2015 and was passed by $62 \%$ of voters (Cahillane, 2018).

Although its role in putting same-sex marriage not only on the political agenda but actually leading to constitutional changes was widely praised, the Convention did come in for criticism regarding its claims to possess either representative or deliberative legitimacy. Eoin Carolan later identified several shortcomings in terms of its composition, agenda, expert advice and the risks of bias and manipulation by elite actors. Indeed, he concluded that it provided "a warning about how the symbolic value of the ordinary citizen can be exploited for political purposes" (Carolan, 2015, p. 733).

Seeing, however, that the Convention had been successful in dealing with a controversial issue and leaving politicians relatively unscathed, in late 2015, Enda Kenny, Ireland's Prime Minister (or Taoiseach) decided to establish a Citizens' Assembly which would meet over five weekends between November 2016 and April 2017, to examine the possible changes to Article 40. 3.3 and make recommendations to the government on the matter. Although chaired by a Supreme Court judge, Mary Laffoy, the Citizens' Assembly displayed one key difference with the Constitutional Convention, namely that it comprised 99 randomly selected citizens. Thus, no politicians would have any hand, act or part in its recommendations.

This was immediately seen by some public commentators, both left and right, as a "cop-out", meaning an abdication of responsibility by Ireland's political class in dealing with the issue of abortion themselves. Writing with his typical sarcasm in the Irish Independent, Ian O'Doherty first questioned whether this was actually democratic:

our tough, visionary leaders have decided that the situation is so dire we need a... Citizens' Assembly. Because sometimes having an actual parliament just isn't enough (...) what's truly striking is the openly cynical cowardice of this delaying tactic. Enda Kenny obviously doesn't want to go down in history as the Taoiseach who introduced abortion to Ireland (...) if the assembly's recommendations are taken on board - and what is the point of forming it if they're not? - will that mean that unelected, but selected, citizens get to have an undue influence on how our legislation is framed? Isn't that what we used to elect politicians for? (O’Doherty, 2016).

Even hard-line left-wing organisations in favour of abortion-on-demand considered the establishment of a Citizens' Assembly an undemocratic display of political cowardice, with the Irish Socialist Party claiming that Ireland's political establishment: 
had hoped to 'park' this proverbial hot potato in a 'Citizens' Assembly', so they could claim they were doing something without actually changing anything (...). The very concept of the Citizens' Assembly is a cop out. Is this not why we elect TDs - to legislate? The Dail [Ireland's lower house] should take its responsibility and finally give this generation a say by calling a Referendum to Repeal the 8th now. It is very clear the government is trying to avoid this - and they will use the Citizens' Assembly if it suits. But that is all they intend to do with it. Already various government sources have made it very clear that what they 'expect' a Citizens' Assembly to suggest is a referendum to preface extremely restrictive legislation (Hanke, 2016).

A more academic discussion of the Citizens' Assembly also considered whether political cynicism and expediency was involved. Anne Marlborough, an Irish lawyer writing in 2016 on the Swedish-based Constitutionnet website, expressed concern that while this appeared: "prima facie, to be an innovative use of a deliberative and participatory assembly to promote citizen engagement in constitutional reform, it has been heavily criticised as a cynical political tactic to remove the issue of abortion from parliamentary consideration. The Government is perceived as being unwilling to tackle the difficulties this controversial subject engenders". Observing that although the Irish parliament included pro-abortion parties, the governing coalition of Fianna Fáil and Fine Gael find themselves conflicted between opposing abortion-on-demand and changing the constitution, as well as divisions on the issue within their respective parties. She concluded, however, that:

Constitutional change appears inevitable. Ireland's current constitutional regime is unpopular domestically and is in violation of several of the state's commitments under international law. The appetite of government for a referendum is, however, absent, so it remains uncertain when one will take place. A Citizens' Assembly has been created, in what is widely viewed as a stalling tactic to avoid the holding of a referendum. This initiative is rejected by pro-choice actors, who are demanding an immediate referendum, and, more vehemently, by pro-life actors who allege that the outcome of the Assembly (that of recommending repeal) has been predetermined. The pro-life movement favours retention of the eighth amendment and rejects the conduct of any referendum on the matter (...). The referral of the constitutional status of abortion to the Citizens' Assembly has been uniformly characterised, by political opinion outside government, by civil society, and by the commentariat, as an act of political cowardice, designed to delay debate on an issue which is long overdue for parliamentary consideration. The sole reason for the establishment of this Assembly is believed to be 
the removal of the eighth amendment from the political agenda, as Government is unwilling to grapple with this sensitive issue (Marlborough, 2016).

In a paper addressed to the European Consortium for Political Research in 2018, Dimitri Courant, a researcher based in Lausanne and Paris, also acknowledged that the real reason for the establishment of the Citizen's Assembly had nothing to do with implementing improvements to the Constitutional Convention by maximizing the participation of citizens over politicians. It was simply because of the politically toxic nature of abortion and the TDs' fear of losing electoral support should they take a public stance on the issue. With some TDs claiming that abortion was sometimes a make or break issue while canvassing for votes on the doorstep, the establishment of the Citizens' Assembly, ostensibly a project espousing "deliberative democracy", was actually a vehicle for the "politics of blame avoidance" (Courant, 2018, p. 8).

A number of pro-life activists opposed the Citizens' Assembly from the outset, citing alleged pro-abortion bias among its members and fears that there was a predetermined outcome. However, as we have seen the pro-choice far-left was also vocally opposed, seeing it as a delaying tactic to dealing with abortion head on (O'Connor, 2016; Pro Life Campaign..., 2016). However, the latter set aside their opposition as soon as it became clear that those in attendance were more inclined towards liberalising abortion than restricting it. The perceived undemocratic nature of a selected but unelected Citizens' Assembly influencing laws was still a matter for debate. As Courant argues it is a possible to view such developments by governments as an effort to institutionalise the public discourse, given the fear and lack of trust of political and media elites now have regarding the political competence of the people, following the Brexit vote in the United Kingdom and the election of Donald Trump in the United States:

This anti-democratic temptation might prevail and lead to an institutionalisation of powerless, enlightened, consultative mini-publics playing the role of the 'Prince's advisor' and 'consultation alibi', allowing for the suppression of direct democracy or participatory mechanisms. The only 'audible' voice of the people would have to be filtered through deliberative, controlled, formal institutions, and all other claims would be deemed irrational. The institutionalisation of a single tailored model could then signify the death of democratic imagination and political experimentation (Courant, 2018, p. 18).

Moreover, Laura Cahillane, a lecturer in Constitutional Law at the University of Limerick, warns that while the tactic ultimately worked regarding the issues of same-sex marriage and abortion: 
... the main fear with such exercises is that they can be used as a way for governments and parliamentarians to abdicate their law reform responsibilities and as a delaying tactic on sensitive issues. Also it is important to remember that ultimately, the Oireachtas is a citizen's assembly and so it is not necessary to farm every question of constitutional or law reform out to such a body to deliberate on for inordinate lengths of time. If such exercises are resorted to too often, they will lose their effect and from a practical perspective it may even become difficult to recruit members. It may also become necessary to have a conversation on whether the model which involves politicians works better in terms of securing parliamentary attention and focus on the reports when published. One lesson which we could take away perhaps is that there is no point in establishing such bodies to consider issues which are not regarded as pressing, divisive, or in need of major debate. Indeed these exercises seem to work best for sensitive issues which otherwise might never be brought before the people due to politicians' natural inclination towards self-preservation (Cahillane, 2018).

\section{The conclusions of the Citizens' Assembly and their impact on the public discourse}

Even while the Citizens' Assembly was conducting its work, the UN Committee on the Elimination of Discrimination against Women urged the Irish government to amend Article 40.3.3, claiming that it "unduly restricts access to abortion". It was also critical of what it saw as "the restrictive legal regime" for abortion contained in the Protection of Life during Pregnancy Bill 2013. On 29 June 2017, however, the Citizens' Assembly submitted its official report and recommendations to the Oireachtas for consideration (First Report, 2017). Its members had listened to 25 experts and had spent over eighty hours discussing and deliberating the subject at hand. They then came to the following conclusions regarding how the law should be changed and to what extent abortion should be permitted.

As regards to their recommendations for what was to be done Article 40. 3. 3, the members of the Citizens' Assembly made the following recommendations by a majority vote:

- That Article 40. 3.3 should not be retained in full (87\%)

- That Article 40. 3.3 should be replaced or amended (56\%)

- That Article 40.3.3 should be replaced with a constitutional provision that clearly grants sole authority the Oireachtas to legislate on matters concerning the termination of pregnancy, and any rights of the unborn 
and the pregnant woman, thus removing it from being a constitutional matter (57\%) (First Report, 2017, p. 3).

The Assembly then voted on the grounds on which abortion was to be permitted and the gestational limits to be imposed, if any, in this legislation. Surprisingly, $64 \%$ of the Assembly voted that the termination of pregnancy without restriction should be lawful. More specifically, of the members who voted on this ballot:

- $48 \%$ recommended that the termination of pregnancy without restriction should be lawful up to 12 weeks gestation age only.

- $44 \%$ recommended that the termination of pregnancy without restriction should be lawful up to 22 weeks gestation age only.

- $8 \%$ recommended that the termination of pregnancy should be lawful with no restriction to gestational age.

Moreover, apart from $72 \%$ of members recommending that a distinction should not be drawn between the physical and mental health of a woman, a majority of members recommended 12 reasons which should constitute lawful grounds for termination of pregnancy in Ireland. These were as follows:

- Real and substantial physical risk to the life of the woman (99\%)

- Real and substantial risk to the life of the woman by suicide (95\%)

- Serious risk to the physical health of the woman (93\%)

- Serious risk to the mental health of the woman (90\%)

- Serious risk to the health of the woman (91\%)

- Risk to the physical health of the woman (79\%)

- Risk to the mental health of the woman (78\%)

- Risk to the health of the woman (78\%)

- Pregnancy as result of rape $(89 \%)$

- The unborn child has a foetal abnormality that is likely to result in death before or shortly after birth (89\%)

- The unborn child has a significant foetal abnormality that is not likely to result in death before or shortly after birth $(80 \%)$

- Socio-economic reasons (72\%) (First Report, 2017, p. 4).

Although the report was published in June, the above results had already been released to the public in April. The reactions of commentators ranged from pleasant surprise to shock. Writing in the Irish Examiner, Alison O'Connor stated:

Much to the surprise of most, except possibly themselves, the majority of citizens voted, among other things, for abortion to be available in Ireland with no 
restrictions as to reasons. The proposal that the assembly discuss the Eighth Amendment to the Constitution was a massive cop out on the part of Taoiseach Enda Kenny. That being said, it made its way into being a highly valuable exercise in deliberative democracy (...). So, that response so beloved of Enda Kenny to those who would ask for the repeal of the Eighth Amendment: 'And what would you replace it with?', now has a definitive answer, provided by the assembly ... For the pro-choice side it can be argued that this answer is 'better' than repeal, in that what has been recommended is that it be replaced with a constitutional provision that explicitly gives the exclusive power to the Oireachtas to legislate to address termination of pregnancy, any rights of the unborn, and any rights of the pregnant woman (...). What was fascinating about that discussion is how incredibly liberal it appeared at times. It was hard to tell how prevalent those views were throughout the assembly, but once the results of the votes were in, it was abundantly clear and a shock to almost all present (...). There is so much cynicism abounding in our society at present; a growing sense that anything which has been organised/established by the Government ends up being so poorly handled as to be almost farcical (...). It would be tragic if the immense work of this assembly is not given the respect it is due by the Oireachtas. They no longer have the excuse of saying they do not know the way forward (O'Connor, 2017).

Therefore, while Kenny's strategy had, on the one hand, worked in forcing the issue to come to a head, it had backfired in recommending a far more liberal abortion regime than anyone had ever envisaged. Writing in the liberal Irish Times, Mary Minihan asked:

How did we get here? A Government led by a socially-conservative Taoiseach set up a Citizens' Assembly, which eventually creates shockwaves by recommending extensive liberalisation of abortion laws" adding that "the consensus in the Oireachtas is that the assembly's recommendations were an overly-liberal interpretation of the current thinking of middle Ireland on the issue." In any case, Kenny had a narrow escape from being labelled "the Taoiseach who introduced abortion to Ireland", having resigned on 17 June due to a domestic scandal concerning the Irish police force. That dubious honour would go to his replacement, Leo Varadkar, who had told fellow TDs in 2014: "I consider myself to be pro-life in that I accept that the unborn child is a human life with rights and I do not support abortion on request or on demand," while viewing the Eighth Amendment as "too restrictive" (Leahy, 2018; Uí Bhrian, 2017). In taking up the post, apart from having an ethnic minority background, Varadkar gained worldwide notoriety for being Ireland's first Taoiseach who was openly gay, something which was perceived as sign of Ireland's increasing modernisation, especially since the legalisation of same-sex marriages just two years earlier. 
Following the report's official publication, journalists sought to examine whether its recommendations were a true reflection of what Irish society wanted regarding changes to its abortion laws. Writing in the Irish Times, Ronan McGreevy pointed out that although $64 \%$ of Assembly members had voted for "terminations without restrictions", a poll commissioned by the same newspaper that May 2017 (meaning very soon after the Assembly vote) had found that only $23 \%$ of the Irish public were in favour of such an option. He commented that "though not representative of the assembly as a whole, their views are reflective of those of a majority of the members. Indeed, of the 72 members of the assembly who gave their reflections for the final assembly report, just two expressed an avowedly anti-abortion stance". Despite the seemingly mismatch between the wishes of the public and the Assembly, Paula Geraghty, one of the Assembly members interviewed by McGreevy, reflected the view of many of its participants that the government now had to act on its recommendations:

It would be a criminal waste of time if they don't do something about this ... With some 99 people, give or take, participating and the amount of money that went into organising it, they have to do something. I would like to think that politicians will listen to us and will listen to the fact that we made our decision following reasoned consideration. They should allow the country to have a vote (McGreevy, 2017).

The international pressure for Ireland to liberalise its abortion laws continued that year. While the UN Committee against Torture welcomed the report of the Citizens' Assembly, it expressed concern "at the severe physical and mental anguish and distress experienced by women and girls regarding termination of pregnancy as a result of the State's policies". However, the Report of the Citizens' Assembly for was submitted for consideration to a new Oireachtas Joint Committee on the Eighth Amendment of the Constitution. In December 2017, after a series of hearings, the Joint Committee published its own report recommending a repeal of the Eighth Amendment and, in line with the Citizens' Assembly's recommendations, the introduction of a replacement constitutional provision making the Oireachtas solely responsible for abortion legislation in Ireland (Report of the Joint Committee, 2017).

Government action was now swift. The following month in January 2018, Simon Harris, the Minister for Health, announced to the Dáil that the government would be implementing the report and hold a constitutional referendum in order to repeal Article 40.3. 3 and make abortion law exclusively a parliamentary matter. However, there were a couple of outstanding matters which threatened to upset the apple cart. 
The first of these was that in 2016 the High Court had ruled that, under the Article 40.3.3, the unborn child had rights beyond the right to life. The Irish government appealed the ruling arguing the only right the unborn had was the right to be born and all other constitutional rights took effect at birth, adding that upholding the High Court decision would have a range of difficult-topredict consequences. With the case brought forward urgently to the Supreme Court in advance of the planned referendum, the court conveniently found the unborn did not possess inherent constitutionally protected rights other than those expressly set out in Article 40. 3. 3, thereby reversing the High Court's ruling that the unborn constituted a child as defined by Article $42 \mathrm{~A}$ of the Irish Constitution. This made a legal challenge to abortion legislation much more difficult and removed all obstacles for the Government from pushing on with its planned referendum and wording (Unborn does not have..., 2018).

The second issue concerned claims that the selection process for the recruitment of the members of the Citizens' Assembly had been compromised when news broke in late February that a recruiter from Red C, the private polling organisation awarded the task, had improperly recruited seven back-up members for meetings in January regarding the manner in which referenda should be held. As the Citizens' Assembly's discussions on abortion had ceased the previous April, this did not directly compromise the recommendations concerning that issue. In fact, a similar controversy had occurred during the Constitutional Convention five years earlier when it turned out that two "randomly selected" members were actually neighbours while another two were married to each other, the chances of such a random occurrence being assessed at 2.5 billion to one (Sheahan, 2013). Although both incidents turned out to be more the result of incompetence than malice, to some pro-life advocates it confirmed their suspicions, rightly or wrongly, that from the beginning the whole recruitment process had been run with a liberal bias towards abortion. For example, Cora Sherlock of the Pro Life Campaign stated "I think there's a question mark over the entire process of the Citizens' Assembly, their recommendations, the Oireachtas committee and indeed the question of whether the Government can even go ahead now and hold a referendum" (Leogue, 2018). There was also strong criticism when it also turned out that 10 out of Ireland's 26 counties had no members at the Assembly, leading to accusations that the voice of rural, conservative Ireland had been deliberately sidelined in the abortion debate (McGreevy, 2018; Citizens' Assembly fiasco..., 2018). There were angry scenes in the Dáil when a small number of pro-life TDs from the counties in questions called for the upcoming abortion referendum to be postponed over the issue, with one of them calling 
the entire process "a stitch-up" (Dáil, descends into row..., 2018). However, as Melanie McDonagh commented in The Spectator,

For backers of repeal such as the Taoiseach, Leo Varadkar, it is a matter of acknowledging realities, namely that some 3,000-4,000 women a year travel to Britain for an abortion, with others obtaining abortifacients online. 'In the Ireland of 2018, we still export our problems and import our solutions,' he said. Repeal is, in this reading, about bringing Ireland into line with modernity. Abortion is, like gay marriage, emblematic of moving forward from a Catholic past (McDonagh, 2018).

\section{The Abortion referendum campaign of May 2018}

In March, a Bill to Regulate the Termination of Pregnancy in Ireland was passed by both houses of the Oireachtas, a decision which was confirmed by the electorate in a referendum held on 25 May 2018, with 66.4\% of voters voting in favour (Ireland's abortion referendum..., 2018). The resulting Health (Regulation of Termination of Pregnancy) Bill 2018 was signed into law on 27 December 2018 and came into force on 1 January 2019.

The referendum campaign itself was the subject of controversy, apart from the highly contentious substantive issue at hand. This concerned the issue of perceived foreign interference in the campaign by American anti-abortion groups using targeted advertising at undecided Irish voters through Facebook and YouTube. There were also attempts to interfere with the crowdfunding operations of the websites of groups supporting the liberalisation of abortion (Conneely, 2018). Writing in the Irish Times, Una Mullay claimed that:

two types of referendum campaign are under way. One is in full view: the posters and debates and daily media reports. The other is in the shadows online, where Ireland has dawdled on regulation and where it is impossible to quantify the impact of the type of advertising, used by Undecided8 [an anti-abortion organisation]. A lot of dark advertising - that is visible only to a targeted group - is rudimentary or crude, with sensational messaging designed to illicit an emotional response. These are the bottom feeders of voter manipulation (Mullay, 2018).

Citing concerns about the integrity of the referendum, Facebook and Google, YouTube's owner, said they were either blocking political advertising of foreign origin or removing it entirely. Right-of-centre commentators viewed this move as the tech giants still smarting over accusations that they allowed fake news and foreign manipulation to run amok during the 2016 US elections and UK's 
Brexit referendum. With both of them having their European headquarters in Dublin, neither Facebook nor Google would allow this to happen again, afraid that if the referendum was defeated by the forces of conservatism, they would get the blame (Dougherty, 2018).

Indeed, writing in the Irish Times, Pat Leahy reported that:

There has been rising concern among some pro-repeal groups and supporters that the referendum could be swayed in its decisive weeks towards a No vote by an avalanche of online ads. Facebook's move is likely to be directly related to this fear: and a fear that if the referendum were defeated, the company would face questions about its role in influencing votes, as it has in the US and UK. In the past fortnight, there has been a rising sense of pessimism in some repeal quarters that the campaign was slipping away from them. Yesterday, the transparency campaigner Gavin Sheridan tweeted that it was now his view that the No side would win the campaign because its online spending was dwarfing that of the Yes campaign (Leahy, 2018).

This led to counter-accusations of the pot calling the kettle black since Amnesty Ireland, one of the main organisations campaigning for abortion to be legalised, had bluntly refused to return $€ 137,000$ in illegal donations from the George Soros-funded Open Society Foundation, despite having been ordered to do so by Ireland's Standards in Public Office Commission (Leogue, 2017). Moreover, conservative commentators recalled how organisations campaigning to introduce same-sex marriage had received over $\$ 16,000,000$ between them from just one American foundation in the period 2001-2011, a campaign which was ultimately successful in 2015 (O'Brien, 2015). Although the Together for Yes campaign claimed that Google's decision regarding the abortion referendum would "ensure a level playing field between both sides", pro-life activists labelled it "a blatant attempt to silence debate in Ireland" (Daly, 2018). The actions of the US tech giants in Ireland did not go unnoticed internationally, with American conservative writers asserting that:

These decisions by Silicon Valley are extremely serious for all conservative activists and publishers who have been investing in using its products for years. If they feel the need to appease center-left critics by pre-emptively disarming Irish pro-lifers, whom will they seek to silence, and throttle, next? (Dougherty, 2018).

However, as Melanie McDonagh observed in The Spectator, the most notable thing about the campaign is that:

it's an almost entirely secular debate. The Catholic Church is absent from the fight to an extent that would have been hard to imagine in 1983, though it has made 
clear its support for keeping the amendment - as indeed have the leaders of the Protestant churches. And that's reflective of the condition of the Church in the wake of successive abuse scandals. (...) For the liberal classes - think Guardian readers in Britain, then square the self-regarding homogeneity - it's a totemic issue, part of a Kulturkampf between modernity and Catholicism (McDonagh, 2018).

\section{Conclusion}

Once the dust had settled following the repeal of the Eighth Amendment, the strategy of using the Citizens' Assembly to break the impasse which had affected the abortion issue in Ireland came in for wide praise, both at home and abroad. Indeed, it was seen as highly successful exercise in "deliberative democracy", an example for others to follow. As Susan McKay, writing in Foreign Policy Magazine, commented:

The assembly's work offered the legislature a means of tackling thorny issues that politicians might have otherwise shied away from and gauging actual public opinion rather than allowing clashing activists to drown out mainstream views. It's a model that other democracies facing controversial social debates can, and should, adopt. Democracies are increasingly resorting to referendums to increase public engagement, awareness, and accountability. Yet a referendum alone can produce greater disorder-Brexit is a case in point-rather than resolution. As Ireland's constitution can be changed only by referendum, the country has discovered that targeted and pre-emptive deliberative processes among selected groups of citizens, who stand in for the public, can enable better societal reflection before referendums-and thus produce a more orderly and widely accepted outcome (McKay, 2019).

Indeed, as late as June 2019, it was even touted by senior British politicians as a way for Britain to deal with Brexit, with Rory Stewart, a candidate in the race to be leader of the British Conservative Party and prime minister of the United Kingdom openly promoting it as a key policy should he win (Stewart, 2019). However, as we have seen, there are three important aspects which should not be ignored in the Irish case.

Firstly, given the strong media coverage the Citizens' Assembly enjoyed due to the controversy of the subject under discussion, the question remains, as Courant has pointed out, as to how precisely it influenced the referendum result, if indeed it did (Courant, 2018, p. 18). Thus, did the Citizens' Assembly reflect or shape the will of the people? If the former, then it is indeed a model to follow; if the latter, it may be called many things but not democratic. 
Secondly, for those who established it, the Assembly turned out to be a case of "be careful what you wish for", in that it introduced a liberal abortion regime which would have been almost unthinkable a few short years earlier. Moreover, as Carolan points out, the impulse to celebrate the role of ordinary people in experiments in deliberative democracy should not lead us to suspend our critical faculties regarding the strengths and weaknesses of citizens' assemblies, with the mere fact of involving individuals in such a process providing "no guarantee that those people will - or indeed should - be listened to" (Carolan, 2015, p. 735). In addition, the participants in a citizens' assembly may end up being directed by the deliberative process set out by its architects rather than by their own convictions.

Thirdly, there is the question of to what degree citizens' assemblies are representative and legitimate. We have seen how publicly-elected representatives farmed out the decision-making process on a controversial issue to an unelected body claiming its legitimacy was based on it being both representative and deliberative, despite academics having subjected such arguments to a degree of empirical scepticism. Given that the deliberative conditions established by citizens' assemblies are akin to those of a political laboratory focused on providing information and expertise in a particular deliberative process, one could argue that by the end of such a process that the "ordinary people" involved become so much better informed than the average voter that they cease to be representative, thereby undermining the entire claim of such bodies to be legitimate in the first place (Carolan, 2015, p. 741).

Finally, we have also seen how, despite the subsequent international praised it garnered, the Citizens' Assembly was clearly established to allow politicians a way of abdicating responsibility over a toxic political issue rather than as an exercise in "deliberative democracy". As Eilis O'Hanlon commented shortly after the tragic death of Savita Halappanavar in 2012: "Irish governments are weak in character even when they are strong in numbers ... this one's dearest wish on abortion is plainly that the people would just shut up about it" (O'Hanlon, 2012).

\section{REFERENCES}

A \& B v. Eastern Health Board and C. (1998). 1 I.R. 464.

Attorney General v. X103. (1992). 1 IR 1.

Bill Digest - Health (Regulation of Termination of Pregnancy) Bill 2018. (2018). Oireachtas Library \& Research Service. 
Cahillane, L. (2018, 3 Dec). Delaying Tactics or Useful Deliberative Exercises? The Irish Citizens' Assembly and the Convention on the Constitution. IACL-AIDC Blog. Retrieved from https://blog-iacl-aidc.org/debate-the-citizens-assembly-in-ireland/2018/12/3/delaying-tactics-or-useful-deliberative-exercises-the-irish-citizensassembly-and-the-convention-on-the-constitution

Carolan, E. (2015). Ireland's Constitutional Convention: Behind the hype about citizenled constitutional change. International Journal of Constitutional Law, 13(3), 733-748.

Carolan, E. (2016). Article 40.3.3 and the law on abortion: A history. [A paper presented to the Citizens' Assembly]. Retrieved from https://www.citizensassembly.ie/en/ Meetings/-Art-40-3-3-and-the-law-on-abortion-a-history-Eoin-Carolan.pdf

Chambers, S. (2009). Rhetoric and the Public Sphere: Has Deliberative Democracy Abandoned Mass Democracy? Political Theory, 37(3), 323-350.

Citizens' Assembly fiasco is a political timebomb that's waiting to explode [Editorial]. (2018, 3 Mar). The Kerryman.

Conneely, A. (2018, 26 May). Yes campaign investigating incident on its fundraising webpage. RTE News.

Contiades, X., \& Fotiadou, A. (eds.). (2017). Participatory Constitutional Change: The People as Amenders of the Constitution. London: Routledge.

Courant, D. (2018). The Curious Institutionalisation of Deliberative Democracy: The Irish Citizens' Assemblies and the Future of Democratic Innovation. [A paper addressed to the European Consortium for Political Research General Conference, Hamburg. Used with the permission of the author].

Dáil descends into row over Citizens' Assembly recruitment criticism. (2018, 22 February). The Journal.ie.

Daly, G. (2018, 9 May). Campaigners warn of "rigged referendum" after Google decision. The Irish Catholic.

Dougherty, M. B. (2018, 9 May). Silicon Valley Deletes the Pro-Life Campaign in Ireland: Are Google and Facebook rigging the referendum? National Review.

Enright, M., Conway, V., de Londras, F., Donnelly, M., Fletcher, R., McDonnell, N., McGuinness, S., Murray, C., Ring, S., \& ui Chonnachtaigh, S. (2015). General Scheme of Access to Abortion Bill 2015. feminists@law 5(1). Retrieved from https://journals. kent.ac.uk/index.php/feministsatlaw/article/view/174

Fifth Progress Report on Abortion (Green Paper). (2000). All-Party Oireachtas Committee on the Constitution, Government of Ireland. Stationery Office.

First Report and Recommendations of the Citizens' Assembly: The Eighth Amendment of the Constitution. (2017). Retrieved from https://www.citizensassembly.ie/en/ The-Eighth-Amendment-of-the-Constitution/Final-Report-on-the-Eighth-Amendment-of-the-Constitution/Final-Report-incl-Appendix-A-D.pdf

Gastil, J., \& Wright, E. O. (2019). Legislature by Lot: Transformative Designs for Deliberative Governance. London and New York: Verso. 
Hancke, K. (2016, 7 Sep). A referendum is a real citizens' assembly. Socialist Party. Retrieved from http://socialistparty.ie/2016/09/a-referendum-is-a-real-citizens-assembly/

Ireland's abortion referendum result in five charts. (2018, 26 May). Irish Times.

Leahy, P. (2018, 11 Jan). Leo Varadkar's shifting view on abortion will be key to campaign. Irish Times.

Leahy, P. (2018, 9 May). Facebook's ban on ads reflects nerves of repeal supporters. Irish Times.

Leib, E. J., \& Elmendorf, C. S. (2012). Why Party Democrats Need Popular Democracy and Popular Democrats Need Parties. California Law Review, 100(1), 69-113.

Leogue, J. (2017, 13 Dec). Amnesty hits out on foreign funding. Irish Examiner.

Leogue, J. (2018, 23 Feb). The Pro Life Campaign says revelations about recruitment practices for the Citizens' Assembly put a "question mark" over whether the Government should hold a referendum on the constitutional ban on abortion. Irish Examiner.

Marlborough, A. (2016, 23 Aug). Irish constitutional debate on abortion and the resort to Citizens' Assemblies. Constitutionnet. Retrieved from http://constitutionnet.org/ news/irish-constitutional-debate-abortion-and-resort-citizens-assemblies

McDonagh, M. (2018, 5 May). The Catholic Church is absent in Ireland's abortion referendum. The Spectator.

McGreevy, R. (2017, 30 Jun). Why did Citizens' Assembly take liberal view on abortion? Irish Times.

McGreevy, R. (2018, 11 Jan). Citizens' Assembly was representative of population, says chair. Irish Times.

McKay, S. (2019, 5 Jan). A Jury of Peers: How Ireland used a Citizens' Assembly to solve some of its toughest problems. Foreign Policy Magazine.

Mullaly, U. (2018, 7 May). The poisonous online campaign to defeat the abortion referendum. Irish Times.

O’Brien, B. (2015, 9 May). Asking questions about funding for referendum campaign: "Groupthink has been exalted to an Irish sacrament". Irish Times.

O’Connor, A. (2017, 24 Apr). Citizens' Assembly shows the way on abortion. Irish Examiner.

O’Connor, W. (2016, 16 Oct). Kenny tells new Citizens' Assembly of online risks. Irish Independent.

O’Doherty, I. (2016, 19 Oct). Citizens' Assembly a cop-out in search for solution to bitter abortion debate. Irish Independent.

O'Hanlon, E. (2012, 18 Nov). This Government must be the one to face facts. Sunday Independent.

O’Sullivan, C., Schweppe, J., \& Spain, E. (2013). Article $40.3 .3^{\circ}$ and the Protection of Life During Pregnancy Bill 2013: The Impetus for, and Process of, Legislative Change. Irish Journal of Legal Studies, 3(3), 1-17. 
Pro Life Campaign says Citizens' Assembly has pre-arranged outcome. (2016, $10 \mathrm{Sep}$ ). RTE News.

Protocol annexed to the Treaty on European Union and to the Treaties establishing the European Communities. (1992). Treaty on European Union (Maastricht Treaty). Retrieved from https://europa.eu/european-union/sites/europaeu/files/docs/body/ treaty_on_european_union_en.pdf

Report of the Joint Committee on the Eighth Amendment of the Constitution. (2017). Houses of the Oireachtas. Retrieved from https://www.citizensassembly.ie/en/ The-Eighth-Amendment-of-the-Constitution/Joint-Oireachtas-Committee-onthe-Eighth-Amendment-of-the-Constitution-/Report-of-the-Joint-Committee-onthe-Eighth-Amendment-of-the-Constitution-.pdf

Sheahan, F. (2013, 16 Feb). Concern as Couple and Set of Neighbours are "Randomly Selected" for Constitutional Body. Irish Independent.

Stewart, R. (2019, 9 Jun). If we really want change, we have to face reality. The Guardian.

Uí Bhrian, N. (2017, 24 Nov). The changing positions of Varadkar and Harris on Abortion. Life Institute. Retrieved from https://thelifeinstitute.net/blog/2017/thechanging-positions-of-varadkar-and-harris-on-abortion

Unborn does not have inherent constitutional rights outside right to life. (2018, 7 Mar). RTE News.

We the Citizens Speak Up for Ireland: Participatory Democracy in Ireland - A Pilot. (2011). Original report available at https://www.atlanticphilanthropies.org/wpcontent/uploads/2015/09/We-the-Citizens-2011-FINAL.pdf

Whelan, N. (2012, 25 Feb). Constitutional Convention Will Have Its Remit Severely Pruned. Irish Times. 